TURIZAM

Volume 21 , Issue 2

$81-89$ (2017)

ORIGINAL

SCIENTIFIC PAPER

\section{Influence of Job Stability on Employees' Perception about Importance of Concrete Measures and Activities of Tourism Policy in the Destination of Cultural Tourism}

\author{
Aleksa Š. VučetićA ${ }^{\text {, Snežana Milošević }}{ }^{B}$ \\ Received: May 2017 | Accepted: July 2017 \\ DOI: 10.18421/TRZ21.02-02
}

\begin{abstract}
This paper seeks to explain the influence of job stability on employees' perception about the importance of concrete measures and activities of tourism policy in the destination of cultural tourism. The research was conducted with employees in the sector of cultural tourism in Montenegro. The sample size was $n=746$, and the main statistical procedure was a multivariate analysis of variance. Data were conducted with interviewing procedure and analyzed by SPSS Statistic software. The main research outcome is that there is a significant difference between employees who have a very stable job and employees who have no stable job in the employees' perception of the importance of concrete measures and activities of tourism policy in the destination of cultural tourism. It is about sample size structure of transitional destination of cultural tourism. This study can help policymakers in the field of tourism policy and cultural tourism to create an optimal set of concrete measures and activities of tourism policy for the destination of cultural tourism. Specifically, the contribution is reflected in the field of influence of job stability on that process and the role of part-time and full-time employees in the sector of cultural tourism.
\end{abstract}

Key words: Job stability of employees, concrete measures and activities of tourism policy, the destination of cultural tourism, Montenegro.

\title{
Introduction
}

Cultural tourism is one of the main types of selective tourism (Heung, Kucukusta, 2013; Marinoski, Korunovski, 2012; Tomljenović, 2006), i.e., a specific form of tourism (Lozano-Oyola, et al., 2012; Luković, 2013; Raj, 2013; Reisinger, 2009). It is a very competitive type of selective tourism on the international market of selective tourism. Many countries try to developed cultural tourism, including Montenegro as a transitional tourism destination.

\footnotetext{
A The University of Montenegro, The Faculty of Tourism and Hospitality, Kotor, Montenegro; aleksavucetic@gmail.com

B The Centre for Foreign Languages Pia Stars, Belgrade, Serbia; snekim@yahoo.com
} 
This type of selective tourism could accelerate the development of underdeveloped regions and improve the standard of living of a local population. That is the main reason why policymakers use cultural tourism as a factor of faster development of destination product. From that point of view, cultural tourism is an important factor of tourism stability of many destinations in the world.

Cultural tourism product of Montenegro is one of the leading sub-product in total tourism product of Montenegro. The main centers of cultural tourism are Kotor, Cetinje, Budva, Herceg Novi, and Podgorica. Montenegro-Dubrovnik is a well-known cluster of cultural tourism on the international market of cultural tourism.

Bearing in mind very important role of cultural tourism in tourism development of Montenegro, a slowdown in its growth and development could produce a very serious problem in the national tourism sector. That could generate a number of problems in the economic, social and political environment of Montenegro, and tourism policymakers are focusing on how to create stimulate measures and activities for the development of cultural tourism. That is the main reason, why it is necessary to know the level of influence of job stability on employees' perception of the importance of concrete measures and activities of tourism policy in the sector of cultural tourism.

\section{Literature Review}

Tourism policy is a strong tool for tourism development (Andraz, et al., 2015; Dwyer, 2015; Goh, Li, Zhang, 2015; Hitrec, Hendija, 2008), and producing development focusing on visitors' needs and expectations (Dredge, Jamal, 2015; Healy, et al., 2016; Kamble, Bouchon, 2014). Tourism policy plays the very important role in the regional economy (Goh, et al., 2015; Jelmer H. G. Jeuring, 2016; Jelmer H. G. Jeuring, Haartsen, 2016; Zhang, McCornac, 2014), and national economy too (Di Pietro, et al., 2014; Hącia, 2014). It plays an important role in the supranational economies, such as European Union (EU). Today, EU tourism policy is well known (Cetinski, Sugar, 2009; Estol, Font, 2016; Hall, et al., 2006).

Tourism policymakers should balance objectives of tourism development between economic and environmental objectives (Dwyer, et al., 2010; Hadjikakou, et al., 2015; Youell, 2010). In this sense, cultural tourism is a type of selective tourism which respects both economic and environmental objectives. This does not mean that cultural tourism just by itself can provide the sustainable tourism development. Today, very important part of the overall tourism policy (Boniface, Cooper, 2009; Martha, Kotsaki, 2014; Saxena, 2006) is a cultural tourism policy (De Esteban Curiel, et al., 2012; Raj, 2013; Richards, 2005; Vatter, 2014).

Cultural tourism is a very popular selective tourism type for many reasons. It is an instrument for reducing poverty and improving welfare (Anderson, 2014; Demonja, 2013; Kantarci, et al., 2015; Knight, Cottrell, 2016), reducing seasonality in tourism destination (Borowiecki, Castiglione, 2014; Carlsen, Butler, 2011) and improving economic and social benefits for local population (Chand, 2013; Parsa, 2015). In particular, cultural tourism is very attractive in transitional and developing countries which have a huge quality of cultural tourism resource, such as Montenegro.

Job stability (Ferreira Freire Guimarães, Silva, 2016; Gössling, et al., 2015; Karatepe, et al., 2014) is a term that explains the stability of a job in any organization in the tourism destination and in this study, it is about the stability of a job in the destination of cultural tourism. Employees who are working in this type of destination could be full-time employees, part- 
time employees and student employees. Full-time employees (Gibbs, et al., 2015; Mattel, 2016; Pan, 2015) have the best stability of job compared to part-time and student employees. Parttime employees (Gibbs, et al., 2015; Kattara El-Said, 2014; Lee, 2014) have a very labile job stability compared to full-time employees. Students employees (DeCenzo, et al., 2013; Greenberg, 2013; Solnet, Hood, 2008; Thompson, et al., 2016) usually work at the weekends (Thompson, et al., 2014), but could work 25 hours per week (Greenberg, 2013). Part-time and student employees are very often named as seasonal workers.

Sector of cultural tourism in any destination needs simulative and synchronized measures and activities of tourism policy. From that aspect, tourism policy measures and activities should be analyzed in many aspects. This study tries to research contribution throughout analyzing the influence of job stability on employees' perception of the importance of concrete measures and activities of tourism policy in the destination of cultural tourism.

\section{Methodology}

Participants in this survey were employees in the destination of cultural tourism in Montenegro (employees in heritage hotels, museums, travel agencies and tourism organizations), with a sample size of $n=746$. The relation between genders was 61.1 percent of female and 38.9 percent of male respondents and between regions 57.8 percent of respondents from the coastal region, 32.8 percent of respondents from the central region, and 9.4 percent of respondents from the northern region.

Independent variable in this study were concrete measures and activities of tourism policy: the law on tourism (IV-1), the law on tourism organizations (IV-2) the law on tourist tax (IV-3), the law on the ski slopes (IV-4), the law on mountain trails (IV-5), the law on rafting (IV6), the law on nature protection (IV-7), the law on the management of wastewater (IV-8), the law on inspection control (IV-9), the law on national parks (IV-10), the regulation on records of tourist traffic (IV-11), the regulation of sport and adventure activities (IV-12), the regulation on the classification and categorization of water (IV-13), the regulations on keeping the guest list (IV-14), the rules on the arrangement of baths (IV-15), the rules on wellness tourism (IV-16), the decision on the revision of the Master Plan of Montenegro (IV-17), the decision on establishment of the Council for sustainable development of tourism (IV-18), the strategy for tourism development of Montenegro (IV-19), the nautical tourism development strategy (IV-20), the spatial plan of Montenegro (IV-21), the spatial plan for specific types of selective tourism $(\mathrm{IV}-22)$, the promotion of Montenegro as a tourist destination (IV-23), the promotion of certain types of selective tourism (IV-24), the privileged credit lines for investment in hotels 4 * and 5 * (IV-25), the privileged lines of credit for entrepreneurial activities in the field of selective tourism (IV-26), the reduction of contributions for new employees in the tourism sector (IV-27), the tax cuts for organizations in the field of health tourism (IV-28), the reduction of customs tariff on imports of equipment and services for the hotel industry (IV-29), the reduction of customs tariff on imports of equipment and services in the field of ecotourism (IV-30), the retraining of unemployed for the needs of the tourism sector (IV-31) and the education of the workforce for the purposes of adventure tourism (IV-32).

Dependent variable in this study is job stability of employees (JS). Respondents in the destination of cultural tourism could answer the question "Is your job stabile?" with: Strongly disagree (JS-1), Disagree (JS-2), Neutral (JS-3), Agree (JS-4), and Strongly Agree (JS-5). For JS-1 ( $j=$ $-2), J S-2(j=-1), J S-3(j=0), J S-4(j=1)$, and JS-5 $(j=2)$. 
Data were analyzed with IBM SPSS Statistics 24 (Field, 2009), and the main statistical procedure was factor analysis and multivariate analysis of variance (Lopez-Bonilla, Lopez-Bonilla, 2014). The main aim is to find significant differences between job stability and concrete measures and activities of tourism policy in the destination of cultural tourism of Montenegro. $\mathrm{H}_{1}$ - There are significant differences in the employees' perception about the importance of concrete measures and activities of tourism policy in the destination of cultural tourism, but that difference could not significantly influence tourism policy making process and the quality of tourism policy.

\section{Results}

Results of Bartlett's test of sphericity are Kaiser-Meyer-Olkin measure of sampling adequacy $=$,956; Approx. Chi-square $=18217,751 ; \mathrm{df}=496$; and Sig. $=$, ooo, what is good to continue with other statistical procedures.

Table 1. Total variance explained

\begin{tabular}{|c|c|c|c|c|c|c|c|}
\hline \multirow{2}{*}{ Components } & \multicolumn{4}{|c|}{ Initial Eigenvalues } & \multicolumn{2}{c|}{ Extraction Sums of Squared Loadings } & $\begin{array}{c}\text { Rotation Sums of } \\
\text { Squared Loadings }\end{array}$ \\
\cline { 2 - 8 } & Total & $\begin{array}{c}\text { \% of } \\
\text { Variance }\end{array}$ & $\begin{array}{c}\text { Cumulative } \\
\%\end{array}$ & Total & $\begin{array}{c}\% \text { of } \\
\text { Variance }\end{array}$ & $\begin{array}{c}\text { Cumulative } \\
\%\end{array}$ & Total \\
\hline F1 & 15,146 & 47,332 & 47,332 & 13,827 & 43,208 & 43,208 & 9,629 \\
\hline F2 & 2,438 & 7,618 & 54,950 & 2,439 & 7,622 & 50,830 & 8,579 \\
\hline F3 & 1,798 & 5,618 & 60,568 & 1,987 & 6,208 & 57,039 & 6,201 \\
\hline F4 & 1,129 & 3,527 & 64,094 &, 892 & 2,787 & 59,826 & 11,523 \\
\hline F5 & 1,009 & 3,154 & 67,248 &, 585 & 1,827 & 61,653 & 9,364 \\
\hline
\end{tabular}

Source: Compiled by the authors

Results from the table 1 have shown that only components $\mathrm{F}_{1}, \mathrm{~F}_{2}, \mathrm{~F}_{3}, \mathrm{~F}_{4}$, and $\mathrm{F}_{5}$ could be used for further research. Cattell's diagram is points on components $F_{1}, F_{2}, F_{3}$, and $F_{4}$, and factor matrix points on components $\mathrm{F}_{1}, \mathrm{~F}_{2}, \mathrm{~F}_{3}, \mathrm{~F}_{4}$, and $\mathrm{F}_{5}$. Comparison of the characteristic value obtained by principal components analysis methodology and with parallel analysis methodology point to accepted components $\mathrm{F}_{1}, \mathrm{~F}_{2}$, and $\mathrm{F}_{3}$.

In the structure matrix is shown that main factor's weight for components: $\mathrm{F} 1$ give the items $\mathrm{F}_{22}$, F21, F18, F19, and $\mathrm{F}_{17}$; $\mathrm{F}_{2}$ give the items $\mathrm{F}_{5}$, F4, F6, F10, and $\mathrm{F}_{13}$; $\mathrm{F}_{3}$ gives the items $\mathrm{F}_{2}, \mathrm{~F}_{1}, \mathrm{~F}_{3}, \mathrm{~F}_{19}$, and $\mathrm{F}_{23} ; \mathrm{F}_{4}$ gives the items $\mathrm{F}_{30} \mathrm{O}, \mathrm{F}_{29}$, F28, F26, and $\mathrm{F}_{25}$; and $\mathrm{F}_{5}$ gives the items F15, F16, F13, F12, and F2o. Using correlation results and results from table communalities for the further research it is necessary to use dependent variables IV-1, IV-2, IV-3, IV-4, and IV-5.

Minimum sample size with the middle impact of simple size on research results for $F$ tests (Doane \& Seward, 2011) and multivariate analysis of variance determine Pillai V $=0.25$, Effect size $f_{2}(V)=0.0666667, \alpha$ error prob. $=0.05$, Power $=0.80$ is $n=190$. Sample size in this survey is $n=746$. 
Table 2. Descriptive

\begin{tabular}{|c|c|c|c|c|c|c|}
\hline Variables & Mean & Trimmed Mean & Variance & Std. Deviation & Skewness & Kurtosis \\
\hline IV-1 & 1,2426 & 1,2979 &, 573 &, 75714 &,- 901 &, 988 \\
\hline IV-2 & 1,1595 & 1,2175 &, 682 &, 82577 &,- 863 &, 746 \\
\hline IV-3 & 1,0375 & 1,1107 &, 785 &, 88610 &,- 828 &, 590 \\
\hline IV-4 &, 4853 &, 5392 & 1,308 & 1,14361 &,- 455 &,- 454 \\
\hline IV-5 &, 5389 &, 5987 & 1,366 & 1,16859 &,- 519 &,- 466 \\
\hline
\end{tabular}

Source: Compiled by the authors

Results from the table indicate that there is no extreme value in the sample, but the assumption of normality of distribution is violated, what is normal for the research in social science. Using Kolmogorov-Smirnov test the minimum value of the maximum deviation for this sample with significant level of alpha .01 is .060, and for IV-1 = ,249, IV-2 $=, 234, \mathrm{IV}-3=, 247, \mathrm{IV}-5=$ ,194, and IV-5 $=, 200$. The assumption of normality of distribution of data is partially violated.

Sample size has no untypical points, and Q-Q plot and Scatter Plot indicate that linearity of the variable is fulfilled. Out of the total number of Spearman correlation, the non-variable combination has value less than ,200, and only the correlation between IV-4 and IV-5 is higher than ,800 $(\mathrm{r}=, 879)$.

The results of Box's test have shown that Box's $M=164,476, \mathrm{~F}=2,657, \mathrm{df}_{1}=60, \mathrm{df}_{2}=$ 68600,518 , and Sig. $=$,ooo. Using Levene's test of equality of error variances and Robust tests of equality of means, the results for all independent variable show Welch and Brown-Forsythe value higher than ,oo1. The assumption of homogeneity of a matrix of variance and covariance is partially violated.

Table 3. Multivariate tests

\begin{tabular}{|c|l|c|c|c|c|c|c|}
\hline \multicolumn{2}{|c|}{ Effect } & Value & F & Hypothesis df & Error df & Sig. & Partial Eta Squared \\
\hline Intercept & Pillai's Trace &, 593 & 214,806 & 5,000 & 737,000 &, 000 &, 593 \\
\hline JS & Pillai's Trace &, 032 & 1,203 & 20,000 & 2960,000 &, 241 &, 008 \\
\hline
\end{tabular}

Source: Compiled by the authors

There is the difference in employees' perception about the importance of concrete measures and activities of tourism policy using job stability as the dependent variable, but it does not show where concretely, and what is the level of that influence.

Table 4. Tests of between-subjects' effects

\begin{tabular}{|c|c|c|c|c|c|c|c|}
\hline Source & $\begin{array}{c}\text { Dependent } \\
\text { Variables }\end{array}$ & $\begin{array}{c}\text { Type III Sum } \\
\text { of Squares }\end{array}$ & df & Mean Square & F & Sig. & $\begin{array}{c}\text { Partial Eta } \\
\text { Squared }\end{array}$ \\
\hline JS & IV-1 & 3,466 & 4 &, 867 & 1,516 &, 196 &, 008 \\
\hline & IV-2 & 4,604 & 4 & 1,151 & 1,694 &, 149 &, 009 \\
\hline & IV-3 & 2,940 & 4 &, 735 &, 936 &, 443 &, 005 \\
\hline & IV-4 & 17,563 & 4 & 4,391 & 3,401 &, 009 &, 018 \\
\hline
\end{tabular}

Source: Compiled by the authors

The results are significant for dependent variable IP-5. Job stability explains 2.1 percent of the variance in the results of measuring employees' perception of the importance of the law on mountain trails. 


\section{Discussion}

After factor analysis had finished, five components were accepted. Those components were: the law on tourism organizations, the law on tourist tax, the law on the ski slopes and the law on mountain trails. Using the F-test it was confirmed that the minimum sample size could be $\mathrm{n}=190$ and sample size in the survey was $\mathrm{n}=746$.

The descriptive test has shown that assumption of normality of distribution of variables' data was partially violated, what is usual in social science researches. Box's test and Levene's test confirmed a violation of an equality variance and covariance of variables partially. Spearman correlation confirmed that non-variable correlation had the characteristic of singularity and only one correlation between variable the law on the ski slopes and the law on mountain trail had the characteristic of multicollinearity.

Multivariate test has shown differences between job stability of employees and their perception of the importance of concrete measures and activities of tourism policy. The test of between-subjects' effects has shown that differences were applied to 2.1 percent of the variance in the results of measuring employees' perception of the importance of the law on mountain trails, and 1.8 percent of the variance in the results of measuring employees' perception of the importance of the law on ski slopes.

Job stability's influence on employees' perception about the importance of concrete measures and activities of tourism policy in the destination of cultural tourism, especially between full-time employees on the one hand, and part-time and student employees on the another hand. Differences were results of the working status of employees because full-time employees have to know many things about tourism policy and their concrete measures and activities and part-time and student employees don't have to know that. Part-time and student employees work in organizations and institutions of cultural tourism only seasonally, and their basic work activities are being a tour guide in museums and specialized travel agencies and auxiliary workers in different sectors and department of heritage hotels. Those job activities exclude knowledge and skills about tourism policy, specifically about concrete measures and activities of tourism policy in the destination of cultural tourism.

\section{Conclusion}

Using the Bonferroni's method of adjustment (Field, 2009), the main significant differences (new alpha is .010) in employees' perception about concrete measures and activities of tourism policy in destination of cultural tourism were manifested between employees who are thinking that their job is very stable and employees who are thinking that their job is not stable $(\mathrm{MD}(\mathrm{I}-\mathrm{J})=, 59729, \mathrm{SD}=, 17731$, Sig. = ,007). A significant difference was shown between fulltime employees on the one hand, and part-time and student employees on the another hand.

The main factor's weight for presented significant difference gave dependent variables: the rules on the arrangement of baths, the rules on wellness tourism, the regulation on the classification and categorization of water, the regulation on sport and adventure activities, and the nautical tourism development strategy. That confirms the fact - significant differences are not manifested in concrete measures and activities of tourism policy that directly influenced the growth and development of cultural tourism in Montenegro.

The research result is significant, but those differences could not significantly influence tourism policy making process and the quality of tourism policy. Employees in the destina- 
tion of cultural tourism have a high level of homogeneity of attitudes about concrete measures and activities that stimulate the growth and development of cultural tourism from the aspect of their jobs stability.

High level of homogeneity of attitudes about tourism policy in the destination of cultural tourism could be the result of some facts. Firstly, heritage hotels, museums, travel agencies, and tourism organizations in Montenegro employed a small number of workers. Secondly, listed type of organization has a small number of seasonal workers. Thirdly, all types of organizations in the destination of cultural tourism except heritage hotels have a very compact human resource structure, from the point of employees' profession.

The study shows that job stability is not variable and in the process of creating tourism policymakers should have used creating concrete measures and activities for the growth and development of cultural tourism. Research limitation is that the sample size was conducted in Montenegro as a transitional tourism destination, and that results could be different in developed tourism destination. Theoretical implication is that this type of research is necessary to implement in all types of selective tourism, and to compare the obtained results. The practical implication is that job stability should not be taken in the process of formulation optimal tourism policy for cultural tourism. Recommendation for future research is to use other socio-demographic variables in this research.

\section{References}

Anderson, W. 2014. Cultural tourism and poverty alleviation in rural Kilimanjaro, Tanzania. Journal of Tourism and Cultural Change 13(3), 208-224.

Andraz, J. M., Norte, N. M., Gonçalves, H. S. 2015. Effects of tourism on regional asymmetries: Empirical evidence for Portugal. Tourism Management 50, 257-267.

Boniface, B., Cooper, C. 2009. Worldwide Destinations: The Geography of Travel and Tourism (5 ed.). Oxford: Butterworth-Heinemann.

Borowiecki, K. J., Castiglione, C. 2014. Cultural participation and tourism flows: an empirical investigation of Italian provinces. Tourism Economics 20(2), 241-262.

Carlsen, J., Butler, R. 2011. Island Tourism: A Sustainable Perspectives. Wallingford: CAB International.

Cetinski, V., Sugar, V. 2009. Education for quality tourism management. Tourism and Hospitality Management 15(2), 229-245.

Chand, M. 2013. Residents' perceived benefits of heritage and support for tourism development in Pragpur, India. Tourism: An International Interdisciplinary Journal 61(4), 379-394.

De Esteban Curiel, J., Antonovica, A., Idoeta, C. M. 2012. Critical Factors and Consumption Patterns of Pergamon Museum's Visitors (Berlin, Germany). Procedia - Social and Behavioral Sciences 65, 313-320.

DeCenzo, D. A., Robbins, S. P., Verhulst, S. L. 2013. Fundamentals of Human Resource Management (11 ed.). Hoboken: John Wiley \& Sons, Inc.

Demonja, D. 2013. Cultural Tourism in Croatia after the Implementation of the Strategy of Development of Cultural Tourism. International Scientific Journal - TURIZAM 17(1), 1-17.

Di Pietro, L., Mugion, R. G., Renzi, M. F. 2014. Cultural technology district: a model for local and regional development. Current Issues in Tourism 17(7), 640-656.

Doane, D. P., Seward, L. E. 2011. Applied Statistics in Business and Economics (3 ed.). New York: The McGraw-Hill Companies, Inc. 
Dredge, D., Jamal, T. 2015. Progress in tourism planning and policy: A post-structural perspective on knowledge production. Tourism Management 51, 285-297.

Dwyer, L. 2015. Computable general equilibrium modelling: An important tool for tourism policy analysis. Tourism and Hospitality Management 21(2), 111-126.

Dwyer, L., Forsyth, P., Dwyer, W. 2010. Tourism Economics and Policy. Clevedon: Channel View Publications.

Estol, J., Font, X. 2016. European Tourism Policy: Its Evolution and Structure. Tourism Management 52, 230-241.

Ferreira Freire Guimarães, C. R., Silva, J. R. 2016. Pay Gap by Gender in the Tourism Industry of Brazil. Tourism Management 52, 440-450.

Field, A. 2009. Discovering Statistics Using SPSS (3 ed.). SAGE Publications Ltd.: London.

Gibbs, C., MacDonald, F., MacKay, K. 2015. Social media usage in hotel human resources: recruitment, hiring and communication. International Journal of Contemporary Hospitality Management 27(2), 170-184.

Goh, C., Li, H., Zhang, Q. 2015. Achieving balanced regional development in China: is domestic or international tourism more efficacious? Tourism Economics 21(2), 369-386.

Gössling, S., Ring, A., Dwyer, L., Andersson, A.-C., Hall, C. M. 2015. Optimizing or maximizing growth? A challenge for sustainable tourism. Journal of Sustainable Tourism 24(4), 527548.

Greenberg, J. S. 2013. Comprehensive Stress Management (13 ed.). New York: McGraw-Hill Companies, Inc.

Hącia, E. 2014. The Development of Tourist Space in Polish Port Cities. Procedia - Social and Behavioral Sciences 151, 60-69.

Hadjikakou, M., Miller, G., Chenoweth, J., Druckman, A., Zoumides, C. 2015. A comprehensive framework for comparing water use intensity across different tourist types. Journal of Sustainable Tourism 23(10), 1445-1467.

Hall, D., Smith, M., Marciszewska, B. 2006. Tourism in the New Europe: The Challenges and Opportunities of EU Enlargement. Wallingford: CAB International.

Healy, N., van Riper, C. J., Boyd, S. W. 2016. Low versus high intensity approaches to interpretive tourism planning: The case of the Cliffs of Moher, Ireland. Tourism Management 52, 574-583.

Heung, V. C. S., Kucukusta, D. 2013. Wellness Tourism in China: Resources, Development and Marketing. International Journal of Tourism Research 15, 346-359.

Hitrec, T., Hendija, Z. 2008. Politika, organizacija i pravo u turizmu (2 ed.). Zagreb: Zagrebačka škola za menadžment.

Jeuring, J. H. G. 2016. Discursive contradictions in regional tourism marketing strategies: The case of Fryslân, The Netherlands. Journal of Destination Marketing E Management 5(2), 65-75.

Jeuring, J. H. G., Haartsen, T. 2016. The challenge of proximity: the (un)attractiveness of nearhome tourism destinations. Tourism Geographies 19/1, 118-141.

Kamble, Z., Bouchon, F. 2014. Tourism Planning and a Nation's Vision: A Review of the Tourism Policy of Sri Lanka. Procedia - Social and Behavioral Sciences 144, 229-236.

Kantarci, K., Uysal, M., Magnini, V. 2015. Tourism in Central Asia: Cultural Potential and Challenges. Toronto: Apple Academic Press.

Karatepe, O. M., Baradarani, S., Olya, H. G. T., Ilkhanizadeh, S., Raoofi, A. 2014. The effects of highperformance work practices on critical performance outcomes: Evidence from the hotel industry. European Journal of Tourism, Hospitality and Recreation 5(3), 49-67. 
Kattara, H. S., El-Said, O. A. 2014. Innovation strategies: The implementation of creativity principles in Egyptian hotels. Tourism and Hospitality Research 13(3), 140-148.

Knight, D. W., Cottrell, S. P. 2016. Evaluating tourism-linked empowerment in Cuzco, Peru. Annals of Tourism Research 56, 32-47.

Lee, C. F. 2014. The Determinants of Hospitality Internship Quality From the Perspectives of Three Stakeholders: A Case From Taiwan. Journal of Hospitality \& Tourism Education 26, 75-86.

Lopez-Bonilla, J. M., Lopez-Bonilla, L. M. 2014. Current Issues in Method and Practice.Holistic competence approach in tourism higher education: an exploratory study in Spain. Current Issues in Tourism 17(4), 312-326.

Lozano-Oyola, M., Blancas, F. J., González, M., Caballero, R. 2012. Sustainable tourism indicators as planning tools in cultural destinations. Ecological Indicators, 18, 659-675.

Luković, T. 2013. Nautical Tourism. Wallingford: CAB International.

Marinoski, N., Korunovski, S. 2012. Tourism in Macedonia in Changing Environment. Procedia-Social and Behavioral Sciences 44, 19-31.

Martha, L., Kotsaki, A. 2014. Ancient Greek Drama and its Architecture as a Means to Reinforce Tourism in Greece. Procedia - Social and Behavioral Sciences 148, 573-578.

Mattel, B. 2016. Catering: A Guide to Managing a Successful Business Operation (2 ed.). Hoboken: John Wiley \& Sons, Inc.

Pan, F. C. 2015. Practical application of importance-performance analysis in determining critical job satisfaction factors of a tourist hotel. Tourism Management 46, 84-91.

Parsa, H. G. (2015. Sustainability, Social Responsibility and Innovations in Tourism and Hospitality. Toronto: Apple Academic Press.

Raj, R. 2013. Cultural Tourism. Wallingford: CAB International.

Reisinger, Y. 2009. International Tourism: Cultures and Behavior. Oxford: Butterworth-Heinemann.

Richards, G. 2005. Cultural Tourism in Europe. Wallingford: CAB International.

Saxena, G. 2006. Beyond mistrust and competition-the role of social and personal bonding processes in sustaining livelihoods of rural tourism businesses: a case of the Peak District National Park. International Journal of Tourism Research 8(4), 263-277.

Solnet, D., Hood, A. 2008. Generation Y as Hospitality Employees: Framing a Research Agenda. Journal of Hospitality and Tourism Management 15(1), 59-68.

Thompson, A. A., Peteraf, M. A., Gamble, J. E., Strickland III, A. J. 2014. Crafting and Executing Strategy: The Quest for Competitive Advantage - Concepts and Readings (20 ed.). New York: McGraw-Hill Education.

Thompson, A. A., Peteraf, M. A., Gamble, J. E., Strickland III, A. J. 2016. Crafting E Executing Strategy: The Quest for Competitive Advantage - Concepts and Cases (2o ed.). New York: McGraw-Hill Education.

Tomljenović, R. 2006. Kulturni turizam. In S. Čorak, V. Mikačić (Eds.), Hrvatski turizam: plavo-bijelo-zeleno (pp. 119-147). Zagreb: Institut za turizam.

Vatter, O. 2014. Communication in Destination Marketing Case Study: Tallinn European Capital of Culture 2011. Procedia - Social and Behavioral Sciences 148, 170-176.

Youell, R. 2010. Travel \& Tourism: Book One (3 ed.). London: T \& T Publishing.

Zhang, R., McCornac, D. C. 2014. Challenges for the International Tourism Industry in Japan

- An Agent for Economic Recovery and Development. AlmaTourism: Journal of Tourism, Culture and Territorial Development 10, 109-124. 